\title{
Electrochemical characterization of organic coatings for protection of historic steel artifacts.
}

E. Cano ${ }^{1 *}$, D. M. Bastidas ${ }^{1}$, V. Argyropoulos ${ }^{2}$, S. Fajardo ${ }^{1}$, A. Siatou ${ }^{2}$, J. M. Bastidas ${ }^{1}$, C. Degrigny ${ }^{3}$

${ }^{1}$ Centro Nacional de Investigaciones Metalúrgicas (CENIM)-Consejo Superior de Investigaciones Cientificas (CSIC), Avda. Gregorio del Amo 8, 28040 Madrid, Spain

${ }^{2}$ Department of Conservation of Antiquities \& Works of Art, Technological Educational Institute of Athens (TEI), Athens, Greece Kalkara, Malta

${ }^{3}$ Heritage Malta (HM), Conservation Division - Diagnostics Science Laboratories (HM),

\section{ABSTRACT}

Electrochemical techniques are mainly known in the field of cultural heritage conservation as a tool for the elimination of corrosion layers or the removal of chlorides. However, these techniques are also a valuable tool for assessing the anti-corrosive efficiency of protective coatings. The aim of this study was to evaluate the performance of different coatings for their use in metallic heritage conservation using polarization resistance $\left(R_{\mathrm{p}}\right)$ and electrochemical impedance spectroscopy (EIS). Carbon steel samples were prepared to simulate the surface composition and morphology of historic steel artefacts, and coated by a conservator-restorer following the common practices in conservation treatments. Three commercial organic coatings have been studied: a microcrystalline wax (Renaissance ${ }^{\mathrm{TM}}$ ) and a methyl acrylate/ethyl methacrylate copolymer resin (Paraloid ${ }^{\mathrm{TM}}$ B-72) dissolved in acetone -both them commonly used in conservation and restoration treatments- and a ethylene copolymer wax emulsion in water (Poligen ${ }^{\mathrm{TM}}$ ES91009), that has not been used so far for this purposes. Four commercial corrosion inhibitor additives were added to the Paraloid ${ }^{\mathrm{TM}}$ B-72 resin and Poligen ${ }^{\mathrm{TM}}$ ES-91009 wax. The additives were commercial preparations with the following known active components: a blend of triazoles (M435), an ammonium salt of tricarboxylic acid (M370), a calcium sulphonate (M109), and a bis-oxazoline (Alkaterge- $\mathrm{T}^{\mathrm{TM}}$ ). $R_{\mathrm{p}}$ and EIS results showed that the best protection of the steel specimens was afforded by Poligen ${ }^{\mathrm{TM}}$ ES-91009 when applied in thick layers. None of the additives have shown a clear improvement of the protection properties of the coatings, and one of them impaired the barrier effect of the coating.

Keywords: organic coatings, conservation, heritage, corrosion, additives, EIS, Rp. 5347425

\footnotetext{
* Corresponding author. E-mail address: ecano@cenim.csic.es Tfn: +34 91 5538900. Fax: +34 91
} 


\section{INTRODUCTION}

From a corrosion and protection point of view, archaeological, historic and artistic artefacts differ from industrial objects in that they are usually coated (partly or totally) with corrosion products developed over years or centuries. These corrosion products are part of the history of the object and, in some cases, conserve important information about the original shape, decoration or manufacturing techniques [1]. Therefore, they need to be at least partially preserved and protective coatings should be applied over them rather than on a clean metal surface.

Coatings used for conservation and restoration treatments should meet a number of special requirements; mainly transparency, a good aesthetic appearance, long-term stability and reversibility. The latter is a vital condition for restoration products, since the treatment applied to an object intended to last for centuries will eventually need to be renewed [2]. It is also very important that protection systems be easy to apply to artifacts of different types and sizes and be safe both for conservators-restorers and the environment. Moreover, most of these coatings are applied to metals already covered, partly or totally, by corrosion products or patinas.

For all these reasons, corrosion protection systems developed for industrial applications may not be suitable for the protection of archaeological, historic and artistic artefacts, and it is necessary to study the protective properties of suitable coatings using a methodology adapted to their special characteristics and requirements [2,3]. A recent survey in different countries in the Mediterranean area has showed that Paraloid ${ }^{\mathrm{TM}}$ B-72 (a methyl acrylate/ethyl methacrylate copolymer) and microcrystalline waxes are, by far, the most common coatings used for protection of copper and iron based historical or archaeological artefacts [4]. However, many failures of the coatings have been reported, and waxes and acrylic resins are usually dissolved in solvents that might be harmful for both the conservators-restorers and the environment. There is a general trend towards the substitution of toxic protection systems by environmentally friendly and low-toxicity products. Solvent-based coatings are being replaced by water-borne ones, in order to reduce the emission of volatile organic compounds. Toxic corrosion inhibitors such as benzotriazole, commonly used in conservation-restoration treatments, are being replaced by less toxic compounds [5]. In this line, corrosion inhibitors from natural products have been extensively studied in recent years [6, 7]. Many extracts from aromatic herb, spices and medicinal plants have been demonstrated to be good corrosion inhibitors for steel [8] and copper [9]. Therefore, there is a need to develop new coatings or test the suitability of already existing ones for their use in this field [2].

Electrochemical techniques are mainly known in the field of cultural heritage conservation in relation with restoration treatments of metallic artefacts, usually the elimination of corrosion layers [10, 11] or the electrochemically-aided removal of chlorides [12-15]. However, these techniques are a very valuable tool and a quick method for assessing the anti-corrosive efficiency of protective coatings and films applied to prevent the further degradation of metal objects. EIS has been extensively used in the last decades for the study of organic coatings for metals [16-18]. It has also been used to assess coatings performance after 
physical or chemical accelerated ageing tests [19-20]. However, their use for the evaluation of coatings for metallic heritage conservation has been much more recent and limited [21-23].

The aim of this paper is to study the protective properties of traditional and innovative (in conservation) organic coatings for their use in conservation and restoration treatments for historic iron artefacts and the effect of doping with four corrosion inhibitor additives, and the applicability of electrochemical techniques to the assessment of those coatings.

All the experimental protocol has been developed with the aim of reproducing as close as possible the real conditions of conservation-restoration treatments of metals [2]. Coatings have been selected amongst commercial products already used by conservators-restorers and other commercial products developed for other applications that fulfil the requirements of metal conservation criteria. Coatings have been applied by a conservator-restorer by hand, as they would be applied in real treatments. Authors are aware that this experimental procedure reduces the reproducibility and produces coatings with a greater degree of inhomogeneity, making more difficult the interpretation of the EIS spectra. But on the other side, it allows for a study of the coatings in conditions that reproduce more closely the real application of the coating in conservation-restoration treatments.

\section{EXPERIMENTAL}

\section{Metallic specimens}

Three sets of $3 \mathrm{~mm}$ thick sheet steel specimens have been analysed. Set 1 and Set 3 consisted of clean steel specimens coated with organic coatings. The difference between boths sets was the method for the application of the coating (see below). Set 2 consisted of pre-corroded steel specimens coated with organic coatings and artificially aged.

The composition of the steel, determined using glow discharge-optical emission spectroscopy was (by weight): $0.13 \% \mathrm{C} ;<0.10 \% \mathrm{Si} ; 0.53 \% \mathrm{Mn} ; 0.010 \% \mathrm{P} ; 0.015 \% \mathrm{~S}$; and balance $\mathrm{Fe}$.

The clean steel specimens (Set 1 and Set 3) were mechanically polished with successive grades of emery paper down to grade 600 , ultrasonically cleaned in ethanol, and stored with silica gel until they were coated.

Steel specimens for Set 2 were pre-corroded in a climate cabinet. They were supported on a polymethyl-methacrylate rack at an angle of 60 degrees from the horizontal and exposed to a 3-day cycle consisting of $100 \%$ relative humidity $(\mathrm{RH})$ at $30^{\circ} \mathrm{C}$ for $24 \mathrm{~h}$ followed by $24 \mathrm{~h}$ in a laboratory environment $\left(55-60 \% \mathrm{RH}\right.$ and $25-30^{\circ} \mathrm{C}$ ) and finally a further $24 \mathrm{~h}$ at $100 \% \mathrm{RH}$ and $30^{\circ} \mathrm{C}$. This protocol has been developed for the preparation of steel specimens with some corrosion pits on the steel surface to resemble the corrosion originated on historic and artistic objects over years or centuries [2, 24]. 
It should be noted that the type of cleaning applied to historic objects during conservationrestoration treatments seeks to remove certain bulky and loose corrosion products but not to completely eliminate the entire corrosion product layer. Surface information on the object (decoration, tool marks, etc.) is in many cases preserved by corrosion products, and conservation ethics therefore require the maintenance of this material.

After the pre-corroding treatment the steel specimens were partly cleaned by a restorer using a protocol similar to that used for the cleaning of objects of historic and artistic value. The specimens were first wiped using cotton swabs wetted with ethanol, to remove powdery corrosion products, and then polished with rotary natural bristle brushes. This procedure did not completely remove all the corrosion products, therefore some corrosion products remained on the surface before the application of the coating.

\section{Coatings}

Table 1 summarises the organic coatings tested. Two commercial coatings commonly used in conservation and restoration treatments were studied, namely Renaissance ${ }^{\mathrm{TM}}$ wax (a microcrystalline wax) and Paraloid ${ }^{\mathrm{TM}}$ B-72 (a methyl acrylate/ethyl methacrylate copolymer ). A new (in conservation treatments) organic coating, Poligen ${ }^{\mathrm{TM}}$ ES-91009, a ready-to-use liquid wax (ethylene copolymer wax emulsion in water), was also studied. Four commercial corrosion inhibitor additives were added to the Poligen ${ }^{\mathrm{TM}}$ ES91009 and the Paraloid ${ }^{\mathrm{TM}}$ B-72. The additives were commercial preparations with the following known active components: a blend of triazoles (Cortec Corporation M435); an ammonium salt of tricarboxylic acid (Cortec Corporation M370); a calcium sulphonate (Cortec Corporation M109); and a bis-oxazoline (Dow Chemical Alkaterge- $\mathrm{T}^{\mathrm{TM}}$ ) (see Table 1).

Coatings for Set 1 were applied by brushing in two criss-cross layers, allowing $24 \mathrm{~h}$ for drying between layers. Coatings for Set 2 were applied by immersion and artificially aged in a climate cabinet, a Voetsch Industrietechnik VC 4034 system, for 30 daily cycles of $90 \% \mathrm{RH}$ at $35^{\circ} \mathrm{C}$ for $16 \mathrm{~h}$ and $55 \% \mathrm{RH}$ at $23^{\circ} \mathrm{C}$ for $8 \mathrm{~h}$. To compare the protective properties of the different coatings before and after artificial aging, seven reference specimens (coated but not artificially aged, $\mathrm{Cx}-\mathrm{N}$ in column six of Table 1) and 7 artificially aged specimens (Cx-A in Table 1) were tested. Figure 1 shows the two samples of Set 2 as they were tested. Finally, to investigate the effect of the coating procedure, clean samples were coated by immersion with the three coatings without additives (Set 3). These samples were not aged.

Table 1 also summarises the thickness of the organic coatings, measured with an Elcometer 300 thickness gauge, using a probe for magnetic materials based on electromagnetic induction. The reported thickness is the average of 20 points in different areas of two different specimens.

\section{Electrochemical techniques}

Three different electrochemical tests were performed: corrosion potential $\left(E_{\text {corr }}\right)$; polarisation resistance $\left(R_{\mathrm{p}}\right)$; and electrochemical impedance spectroscopy (EIS). A classic three-electrode configuration cell was used. The working electrode was the surface $\left(4.15 \mathrm{~cm}^{2}\right)$ of the steel specimen exposed to the 
electrolyte, the counter electrode was a large surface area platinum mesh, and the reference electrode was a saturated calomel electrode (SCE). Experiments were performed after $1 \mathrm{~h}$ of stabilisation of the $E_{\text {corr }}$. After that time, the potential remained stable. It should also be pointed out that the coatings under study were intended to be used for indoor protection of metals, and therefore long immersion times were not considered to be representative of the real conditions of exposure of the coatings. Figure 2 shows a scheme of the electrochemical cell used.

Two electrolytes were tested to simulate the type of pollutants found in museum environments: a $0.1 \mathrm{M} \mathrm{NaCl}$ solution and a dilute Harrison's electrolyte $\left(0.35 \mathrm{wt} \%\left(\mathrm{NH}_{4}\right)_{2} \mathrm{SO}_{4}+0.05 \mathrm{wt} \% \mathrm{NaCl}\right.$ in distilled $\mathrm{H}_{2} \mathrm{O}$ ) [25], using a volume of $20 \mathrm{ml}$.

Both electrolytes ( $\mathrm{NaCl}$ and Harrison) have been used for $R_{\mathrm{p}}$ measurements of Set 1. Since no significant differences were observed between the two electrolytes, EIS measurements of Set 1 and $R_{\mathrm{p}}$ and EIS measurements of Set 2 were carried out using a $0.1 \mathrm{M} \mathrm{NaCl}$ electrolyte only.

An EG\&G PARC 273A potentiostat was used for $R_{\mathrm{p}}$ measurements. The potential was swept from $E_{\text {corr }} \pm 10 \mathrm{mV}$ at a scan rate of $0.16 \mathrm{mV} / \mathrm{s}$. A Solartron 1250 Frequency Response Analyser connected to an EG\&G PARC 273A potentiostat was used for EIS measurements, applying a logarithmic sweeping frequency of 5 steps per decade, from $64 \mathrm{kHz}$ to $64 \mathrm{mHz}$. Impedance measurements were performed at the $E_{\text {corr, }}$ imposing a sinusoidal signal of $10 \mathrm{mV} \mathrm{rms}$.

\section{RESULTS AND DISCUSSION}

The visual appearance of the specimens is an important parameter to take into account when dealing with coatings intended for use in cultural heritage conservation and restoration treatments. Although this is a subjective matter, it is very important that a coating applied to a metal does not alter its visual aspect. It is desirable to have little (if any) colour change. From this point of view, the three studied organic coatings performed well, since they are transparent.

In the case of bare metals, the metallic shine also needs to be preserved. In this respect, some differences were observed. The best appearance was afforded by the Renaissance ${ }^{\mathrm{TM}}$ coating, since the aspect of the steel is "ideal" (no changes were observed). In contrast, the Paraloid ${ }^{\mathrm{TM}}$ B-72 coating yields a very glossy plastic-like aspect, and it is difficult to get a visually uniform coating. The visual appearance of the specimens coated with Poligen ${ }^{\mathrm{TM}}$ ES-91009 is half-way between the Renaissance ${ }^{\mathrm{TM}}$ and Paraloid ${ }^{\mathrm{TM}}$ B- $^{-}$ 72 coatings. The aspect is slightly glossy, but the coating is more uniform than with Paraloid ${ }^{\mathrm{TM}} \mathrm{B}-72$.

Table 1 (column three) shows the thickness of the coatings applied by brushing to clean samples (Set 1). Important differences can be observed in the thickness of the coatings, and this parameter should therefore be taken into account when comparing the protective properties of the different coatings. There is also considerable scatter, with a high standard deviation (see column four), in the thicknesses measured in different areas of the specimens. 
Figure 3 shows the $E_{\text {corr }}$ for the different specimens (Set 1) after $1 \mathrm{~h}$ in contact with the $\mathrm{NaCl}$ and Harrison electrolytes. It can be seen that the application of the coatings shifts the $E_{\text {corr }}$ towards more noble values (i.e. less negative potentials); except in the case of specimen 1 (Renaissance ${ }^{\mathrm{TM}}$ wax), which yields similar potential values to the uncoated specimen. The highest $E_{\text {corr }}$ value is shown by specimen $2 \mathrm{a}$ (Poligen ${ }^{\mathrm{TM}}$ ES-91009 + M435 corrosion inhibitor).

Figure 4 shows the $R_{\mathrm{p}}$ measurements for the different specimens (Set 1). It can be seen that specimen 1 (Renaissance ${ }^{\mathrm{TM}}$ wax) showed poor protective properties, yielding a similar $R_{\mathrm{p}}$ value to the uncoated steel $\left(\sim 10^{3} \Omega \mathrm{cm}^{2}\right)$. Specimens coated with Poligen ${ }^{\mathrm{TM}}$ ES-91009 showed better protection, especially when doped with M435 and M370 corrosion inhibitors (specimens $2 \mathrm{a}$ and $2 \mathrm{~b}$ ), yielding an $R_{\mathrm{p}}$ value of $\sim 10^{6} \Omega \mathrm{cm}^{2}$. However, it should be taken into account that specimens $2 \mathrm{a}$ and $2 \mathrm{~b}$ are much thicker than specimen 2 , so the increase in the barrier effect due to the thickness increase might also play an important role in the increase of the $R_{\mathrm{p}}$ values. Specimens coated with Paraloid ${ }^{\mathrm{TM}}$ B-72 resin also afford good protection $\left(\sim 10^{5} \Omega \mathrm{cm}^{2}\right)$, although in this case the addition of a corrosion inhibitor does not improve the protective effect in all cases (protection higher for specimen $3 \mathrm{~b}$ but similar for specimen $3 \mathrm{c}$ ). In the case of specimen 3a the M435 corrosion inhibitor greatly impairs the protective properties of the Paraloid ${ }^{\mathrm{TM}} \mathrm{B}$ 72 resin. Since all the Paraloid ${ }^{\mathrm{TM}}$ B-72 based coatings have similar thickness, the differences between them can be attributed to the effects of the additives.

It should be noted that being commercial preparations, and therefore with an unknown exact composition, it is difficult to establish the reason for the failure of the coating $3 \mathrm{a}$, since many components of the product may interact with the polymer, with the metal itself or interfere with the adhesion of the coating to the substrate. M435 is, according to the manufacturer, a blend of triazoles. The mechanism of inhibition of triazoles is based on its adsorption on the metal surface. Therefore, the efficiency of this corrosion inhibitor additive greatly depends on the ability of the electrolyte to transport the inhibitor to the coating-metal interface. These additives are effective only if their solubility is in the right range: if it is too low, insufficient inhibitor molecules will reach the metal surface to be effective; if it is too high, the additive will be leached from the coating and/or cause osmotic blistering or delamination [26]. Triazole is very soluble in water, and it is known to cause blistering of organic coatings when in contact with moisture, and therefore is not suitable to be used for organic coatings unless it is modified to control its solubility [27]. The geometry of the defects and the composition of the electrolyte have also been demonstrated to have a significant effect of the efficiency of inhibitor doped coatings [28]

Figures 5 and 6 show the Bode plots obtained using EIS data for the steel specimens with and without organic coatings (Set 1). It can be seen that on specimens 1 and 2 the coatings do not provide significant protection to the base steel, since the impedance modulus $(|Z|)$ values (see Fig. 5a) are quite close to those of the uncoated specimens. On the other hand, on specimens $2 \mathrm{a}$ and $2 \mathrm{~b}$ the coatings yield an increase of 2-3 orders of magnitude in the $|Z|$ values. The coatings on specimens $3,3 \mathrm{~b}$ and $3 \mathrm{c}$ show good protective properties (see Fig. 6), but the addition of corrosion inhibitor additives decreases their protective properties. Table 2 lists the values of the electrical parameters of the different elements used to fit the EIS data, according to the equivalent electrical circuit in Figure 7. 
EIS results are usually discussed by means of an equivalent electrical circuit that represents the physical properties of the steel/coating system. The circuit in Fig. 7 includes a resistor $\left(R_{\mathrm{s}}\right)$ modelling the resistance of the electrolyte, in series with a constant phase element $\left(\mathrm{CPE}_{1}\right)$ in parallel with another resistor $\left(R_{1}\right)$, that model the properties of the coating, and in series with a circuit constituted by $\mathrm{CPE}_{2}$ and $R_{2}$ elements in parallel modelling the double-layer capacitance and the charge transfer resistance, respectively $[16,17,29-32]$.

A CPE is commonly used instead of a capacitor to model the behaviour of many electrochemical systems showing depressed semicircles in the Nyquist plot. The impedance of a CPE is defined by the empirical expression: $Z_{\mathrm{CPE}}=\frac{1}{Y(\mathrm{j} \omega)^{\alpha}}$ where $Y$ is a constant, $j=(-1)^{1 / 2}, \omega=2 \pi f$, and the exponent $\alpha$ is $-1 \leq \alpha \leq+1$. When $\alpha=0$, the CPE is a resistor; when $\alpha=1$, the CPE is a capacitor; and when $\alpha=-1$, the CPE is an inductor. Finally, if $\alpha=0.5$, the CPE is the Warburg impedance, i.e. models a diffusion process [33-34]. The use of a CPE instead of an "ideal" capacitor is attributed to different reasons, such as surface roughness, inhomogeneous distribution of the reaction rates or the current, or differences in the thickness or properties of a coating (as it has been shown in Table 1). Therefore, CPEs with values of the exponent about 0.8 in Table 2 can be interpreted as "non-ideal" capacitors. The $\mathrm{CPE}_{1}$ and $R_{1}$ elements in Fig. 7 may be assigned to the organic coating behaviour, and the "nested circuit" elements $\mathrm{CPE}_{2}$ and $R_{2}$ may be assigned to the steel corrosion process at the bottom of the pores on the coating. The "nested circuit" model is applicable only to coatings that have defects or pores which allow the electrolyte to penetrate the coating down to the steel $[16,17]$.

Table 2 summarises that the $Y_{2}$ and $R_{2}$ values for specimen 1 are similar to those of the uncoated specimen 0 and that the coating resistance is extremely low $\left(\sim 23 \Omega \mathrm{cm}^{2}\right)$, indicating poor protective properties of Renaissance ${ }^{\mathrm{TM}}$ wax. This result agrees with the $R_{\mathrm{p}}$ results of Fig. 4. SEM images (Figure 8) of specimen 1 showed that large pores are visible and justify the use of the equivalent electrical circuit of Fig. 7.

In the case of specimens $2,2 \mathrm{a}$ and $2 \mathrm{~b}$ nor large pores neither cracks were observed by SEM (Fig. 8), but the appearance of two time constants in the EIS spectra indicate that the electrolyte reaches the surface of the metal through microscopic pores or defects of the coating. For such coatings, Skale et al. have proposed that the diffusion of species through the pores of the coating controls the corrosion rate [34], and that this can be modelled using the Warburg impedance. In Table 2 (specimens 2, 2a and $2 \mathrm{~b}$ ) the exponent $\left(\alpha_{2}\right)$ of $\mathrm{CPE}_{2}$ is around 0.5 , and therefore the $\mathrm{CPE}_{2}$ element is a Warburg impedance. On the other hand, the values of the exponent $\left(\alpha_{1}\right)$ of $\mathrm{CPE}_{1}$ range from 0.76 to 0.96 , and can be attributed to the "nonideal" capacitive behaviour of the coating. The low value of $R_{1}$ for coating 2 (close to the resistance of the uncoated specimen) indicates that coating 2 , applied in this small thickness $(\sim 1 \mu \mathrm{m})$ provides a very low protection, as was already seen in $R_{\mathrm{p}}$ data. The values of $R_{1}$ increase from specimen 2 to specimens $2 \mathrm{a}$ and $2 \mathrm{~b}$, indicating that the latter afford better protective properties. In addition to the effect of the corrosion inhibitor additives, that improvement can also be explained by the higher thickness of the later coatings. 
For specimens 3, 3a, 3b and 3c (see Table 2) the low values of the $\alpha_{1}$ exponent do not allow a classic interpretation of the $\mathrm{CPE}_{1}$ element. SEM images (Fig. 8) showed that in this case the coating is not as uniform as in the case of specimens 2, $2 \mathrm{a}$ and $2 \mathrm{~b}$, showing some cracks and irregularities. The values of the $\alpha_{2}$ exponent are close to 0.5 (Table 2), indicating a diffusion process; probably through the corrosion products inside cracks, pores and/or defects in the coating. The highest resistance value $\left(R_{1}\right)$, and therefore the best protective properties, is yielded by specimen $3 \mathrm{~b}$. In contrast, the $R_{1}$ value of specimen $3 \mathrm{a}$ is lower than that of the coating without any corrosion inhibitor (specimen 3 ). As it has been already mentioned, the $R_{1}$ value is attributed to the resistance of the electrolyte in the ionically conducting paths across the coating. Its low value in specimen $3 \mathrm{a}$ indicates therefore that the barrier effect of the coating is almost completely lost.

Table 1 (column six) shows the average thickness of the different coatings applied by immersion to the pre-corroded steel surface (Set 2). Some differences can be observed between those with Paraloid ${ }^{\mathrm{TM}}$ B-72 as opposed to Poligen ${ }^{\mathrm{TM}}$ ES-91009, with or without corrosion inhibitor additives. There is also considerable scatter in the thickness measured across the specimen surface, see the standard deviations shown in Table 1 (column seven).

Figure 9 shows $R_{\mathrm{p}}$ measurements using $\mathrm{NaCl}$ electrolyte for pre-corroded specimens with and without ageing (Set 2). For the Poligen ${ }^{\mathrm{TM}}$ ES-91009 coatings, the aged specimens seem to perform slightly better than the reference ones. On the other hand, the Paraloid ${ }^{\mathrm{TM}} \mathrm{B}-72$ based coatings show a decrease in $R_{\mathrm{p}}$ values with ageing that cannot be attributed only to thickness differences between the specimens.

As for the clean steel surface specimens (Fig. 4, Set 1), the lowest protection was afforded by the Renaissance ${ }^{\mathrm{TM}}$ wax (specimens $\mathrm{C} 1-\mathrm{N}$ and $\mathrm{C} 1-\mathrm{A}$ ). The highest $R_{\mathrm{p}}$ value (i.e. the best protective properties) is afforded by the Poligen ${ }^{\text {TM }}$ ES-91009 coating without corrosion inhibitor additives (specimens C2-N and C2-A). In this case, the addition of corrosion inhibitors to the Poligen ${ }^{\mathrm{TM}}$ ES-91009 wax yielded poor protection (specimens $\mathrm{C} 2 \mathrm{a}-\mathrm{N}, \mathrm{C} 2 \mathrm{a}-\mathrm{A}, \mathrm{C} 2 \mathrm{~b}-\mathrm{N}$ and $\mathrm{C} 2 \mathrm{~b}-\mathrm{A}$ ). The differences with specimens of Set 1 (coatings $2 \mathrm{a}$ and $2 \mathrm{~b}$ ), where the additives improved the protection properties of the coating, can be explained by the differences in the thickness of the coating: at high thicknesses, the predominant effect is the physical barrier effect, but at low thicknesses, the barrier effect of the coating is lower and its higher permeability to the electrolyte favour the solubility of the inhibitor and its transport to the surface of the metal [35].

Paraloid ${ }^{\mathrm{TM}} \mathrm{B}-72$ coatings also provide good protection. Although they show lower $R_{\mathrm{p}}$ values than Poligen ${ }^{\mathrm{TM}}$ ES-91009, it should be taken into account that in this set of specimens the thickness of the Paraloid $^{\mathrm{TM}}$ B-72 coatings was much lower than that of the Poligen ${ }^{\mathrm{TM}}$ ES-91009 coatings, making a direct comparison between them difficult. For Paraloid ${ }^{\mathrm{TM}}$ B-72, corrosion inhibitor additives did not improve the protective properties of the coating. Even though specimens $\mathrm{C} 3 \mathrm{~b}-\mathrm{N}$ and $\mathrm{C} 3 \mathrm{c}-\mathrm{N}$ show a high $R_{\mathrm{p}}$ compared to specimens $\mathrm{C} 3-\mathrm{N}$, after artificial aging the $R_{\mathrm{p}}$ of the coatings with both corrosion inhibitor additives (C3b-A and $\mathrm{C} 3 \mathrm{c}-\mathrm{A}$ ) is more than one order of magnitude lower than that of the coating without corrosion inhibitor (C3-A). 
Figure 10 shows Bode plots obtained using EIS data for the pre-corroded steel specimens with and without organic coatings (Set 2) without ageing. EIS spectra have been modelled using the equivalent electrical circuit shown in Fig. 7. The values obtained for the different elements of the circuit are shown in Table 3.

The behaviour of these specimens is very similar to those of Set 1 . The main difference appears in the sample without coating, where two processes can be observed. In this case, the second process, that does not appear in specimen 0 of Set 1 can be attributed to the effect of the corrosion products on localized areas of the surface. The effect of those corrosion products is not visible in the coated samples, where only the response of the coating $\left(R_{1}-\mathrm{CPE}_{1}\right)$ and the dissolution of the metal $\left(R_{2}-\mathrm{CPE}_{2}\right)$ can be observed. The EIS response of the corrosion products and inhibitor additives is probably concealed by the other processes.

The best protection according to EIS results is provided by coatings $\mathrm{C} 2$ (Poligen ${ }^{\mathrm{TM}}$ ) and $\mathrm{C} 2 \mathrm{~b}$ (Poligen $^{\mathrm{TM}}+\mathrm{M} 370$ ), that yield the higher resistance of the coating and very low pseudo-capacitance (in the order of $\left.10^{-10} \mathrm{~F} \mathrm{~cm}^{-2} \mathrm{~s}^{-(1-\alpha 1)}\right)$ which may be attributed to the high thickness of the layer.

The differences in thickness and in the coating application method (brush or immersion) make difficult in some cases to compare the results between the coatings applied on a clean steel surface (Set 1) or a pre-corroded steel surface (Set 2). In order to investigate the effect of the application method, few additional measurements (Set 3 ) were made on clean specimens coated by immersion with Renaissance ${ }^{\mathrm{TM}}$ wax (specimen X1), Poligen ${ }^{\mathrm{TM}}$ ES-91009 (specimen X2) and Paraloid ${ }^{\mathrm{TM}}$ B-72 (specimen X3). Table 1 shows in the last 3 columns the average and standard deviation of the thickness of the coatings. Results are very similar to those of Set 2, showing that the immersion method produces a thicker layer for Renaissance $^{\mathrm{TM}}$ wax and Poligen ${ }^{\mathrm{TM}}$ ES-91009, while the thickness is similar regardles of the application method for Paraloid ${ }^{\mathrm{TM}}$ B-72.

Figure 11 shows $R_{\mathrm{p}}$ results of the coatings applied by brushing on clean samples (Set 1, specimens 1, 2 and 3), by immersion on pre-corroded samples (Set 2, specimens C1, C2 and C3) and by immersion on clean samples (Set 3, specimens X1, X2 and X3). In the case of Renaissance ${ }^{\mathrm{TM}}$ wax, the increase in the coating thickness on the specimens in Set 3 produced a significant increase in the resistance of the coating. However, when applied on pre-corroded samples (Set 2) did not lead to a similar increase in $R_{\mathrm{p}}$ values, and only a slight improvement was observed.

Paraloid ${ }^{\mathrm{TM}}$ B-72 based coatings have similar thicknesses in the three sets: $\sim 5-10 \mu \mathrm{m}$. All these coatings present higher $R_{\mathrm{p}}$ values on specimens coated by immersion (Set 2 and Set 3 ). Since the coating thickness is similar in specimens of all Sets, this improvement in protective properties may be attributed to the different application methods. Application by immersion (Set 2 and Set 3 ) seems to produce a more uniform layer than application by brushing (Set 1), which in the case of Paraloid ${ }^{\mathrm{TM}} \mathrm{B}-72$ produces a nonuniform layer where the brush strokes can be seen, leaving therefore weak points where the thickness of the coating is lower. 
In the case of the Poligen ${ }^{\mathrm{TM}}$ ES-91009 based coatings there is a large difference in thickness, and the coatings are much thicker on the specimens coated by immersion (Set 2 and Set 3). In this case the increase in thickness produces a 3 orders of magnitude increase in the protective properties of the coating for the Poligen ${ }^{\mathrm{TM}}$ ES-91009 without corrosion inhibitor additives, for both clean and pre-corroded samples. However, in the case of coatings with corrosion inhibitor additives (specimens $\mathrm{C} 2 \mathrm{a}$ and $\mathrm{C} 2 \mathrm{~b}$ ) there is no increase in the $R_{\mathrm{p}}$ values with the thickness. This may be explained because in these cases the protection afforded by the barrier effect (which increases with the thickness) is not the only protection mechanism. The presence of corrosion inhibitor additives may have two opposing effects: on one hand they may increase the protective properties of the coating due to their inhibitive effect, but on the other hand, corrosion inhibitor additives may interact with the coating itself, affecting the cross-linking of the coating [36], or affecting the wetting properties of the binder emulsion with respect to the substrate or the pigments $[37,38]$. A detailed study of the effects of the additives on the properties of the coating would require further research that is out of the scope of this paper.

Figure 12 shows Bode plots obtained using EIS data for the specimens of Set 3. EIS spectra have been modelled using the equivalent electrical circuit shown in Fig. 7. The values obtained for the different elements of the circuit are shown in Table 4. There is a good agreement between EIS and $R_{\mathrm{p}}$ data, and similar features to the fitting of Set 2 EIS data (Table 3) can be observed: $\mathrm{CPE}_{1}$ values show very low pseudo-capacitances as can be expected from these thick coatings, and $R_{1}$ values are in the range of few tenths to few hundreds of kilo ohms, slightly higher than those obtained for the pre-corroded samples. As with specimens from Set 2, $\alpha_{2}$ values are close to 0.5 , showing a significant contribution of diffusive effects.

In general, the EIS results agree with results obtained using the $R_{\mathrm{p}}$ technique. The main advantage of the $R_{\mathrm{p}}$ method is that the interpretation of $R_{\mathrm{p}}$ results is usually easier than with EIS results. However, EIS provides much more in-depth information on the behaviour of the organic coating and the corrosion processes that take place, including mass transport processes.

\section{CONCLUSIONS}

According to electrochemical tests, the best protection for the steel specimens is afforded by Poligen ${ }^{\mathrm{TM}}$ ES-91009 when applied by immersion, producing thick layers $(\sim 40 \mu \mathrm{m})$. When the thickness of the coating is one order of magnitude lower, its protective properties decrease sharply, but continue to provide significant protection. The addition of corrosion inhibitor additives did not lead to a clear improvement in protection. Poligen ${ }^{\mathrm{TM}}$ ES-91009 is also favoured by its uniform appearance and more natural aspect, which is an important factor to be taken into account for coatings used in conservationrestoration treatments.

The worst protection is provided by Renaissance ${ }^{\mathrm{TM}}$, which only increased the $R_{\mathrm{p}}$ and impedance values of the specimens by a very small amount when applied by immersion with a thickness of $\sim 10 \mu \mathrm{m}$. When applied in a very thin layer $(\sim 1 \mu \mathrm{m})$ on the clean specimens, no protection was provided. 
The performance of Paraloid ${ }^{\mathrm{TM}}$ B-72 fell in between that of the Poligen ${ }^{\mathrm{TM}}$ ES-91009 and Renaissance $^{\mathrm{TM}}$ coatings. However, its appearance was the worst (it has a more "plastic-like" aspect than Poligen ${ }^{\mathrm{TM}}$ ES-91009). The addition of M109 and Alkaterge-T corrosion inhibitor additives to Paraloid ${ }^{\mathrm{TM}}$ B72 produced an initial increase in the protective properties of the coatings but ${ }_{2}$ after artificial ageing the $_{2}$ behaviour of the coatings were worse than the Paraloid ${ }^{\mathrm{TM}}$ B-72 without corrosion inhibitor additives. The addition of M435 corrosion inhibitor sharply decreased the protection of the coating, yielding $R_{\mathrm{p}}$ and EIS values similar to the uncoated steel. When applied by immersion, the coating is more uniform and the protection attained is better than when applied by brushing.

\section{ACKNOWLEDGEMENTS}

The authors express their gratitude to the Sixth Framework Programme of the European Commission for financial support of PROMET Project (Contract 509126). D.M. Bastidas expresses his gratitude to the CSIC of Spain for his contract under the I3P Program, co-financed by the European Social Fund.

\section{REFERENCES}

1. Neff D, Dillmann P, Bellot-Gurlet L, Beranger G (2005) Corros Sci 47:15

2. Degrigny C, Argyropoulos V, Pouli P, Grech M, Kreislova K, et al. (2007) The methodology for the PROMET project to develop/test new non-toxic corrosion inhibitors and coatings for iron and copper alloy objects housed in Mediterranean museums. In: Degrigny C, Van Lang R, Joosten I, Ankersmith B (eds) Metal 07. Proceedings of the Interim meeting of the ICOM-CC Metal WG vol 5, Amsterdam (The Neatherlands). Rijksmuseum Amsterdam, Amsterdam, pp 31-37

3. Muresan L, Varvara S, Stupnišek-Lisac E, Otmačić H, Marušić K, Horvat-Kurbegović S, Robbiola L, Rahmounif K, Takenouti H (2007) Electrochim Acta 52:7770

4. Argyropoulos V, Giannoulaki M, Michalakakos GP, Siaotou A (2007) A survey of the types of corrosion inhibitors and protective coatings used for the conservation of metal objects from museum collections in the Mediterranean basin. In: Argyropoulos V, Hein A, Abdel Harith M (eds) Strategies for Saving our Cultural Heritage. Proceedings of the International Conference on Conservation Strategies for Saving Indoor Metallic Collections, Cairo (Egypt). TEI of Athens, Athens, pp 166-170

5. Bastidas JM, Pinilla P, Cano E, Polo JL, Miguel S (2003) Corros Sci 45:427

6. Raja PB, Sethuraman MG (2008) Mater Lett 62:113

7. Rajendran S, Ganga Sri V, Arockiaserlvi J, John Amalraj A (2005) Bull Electrochem 21:367 
8. Abdel-Gaber AM, Abd-El-Nabey BA, Sidahmed IM, El-Zayady AM, Saadawy M (2006) Corros Sci 48:2765

9. Valek L, Martinez S (2007) Mater Lett 61:148

10. Degrigny C, Jerôme M, Lacoudre N (1993) Corros Australas 18:16

11. Bernard MC, Dauvergne E, Evesque M, Keddam M, Takenouti H (2005) Corros Sci 47:663

12. Walker R (1996) Brit Corros J 31:69

13. Campbell SA, Gillard SP, Beech IB, Davies W, Monger G, Lawton P, (2005) Trans Inst Metal Finish 83:19

14. Guilminot E, Baron G, Memet JB, Huet N, Le Noc E, et al. (2007) Electrolytic treatment of archaeological marine chloride impregnated iron objects by remote control. In: Degrigny C, Van Lang R, Joosten I, Ankersmith B (eds) Metal 07. Proceedings of the Interim meeting of the ICOMCC Metal WG vol 3, Amsterdam (The Neatherlands). Rijksmuseum Amsterdam, Amsterdam, pp $38-43$

15. Dalard F, Gourbeyre Y, Degrigny C, (2002) Stud Conserv 47:117

16. Murray JN (1997) Prog Org Coat 31:375

17. Mansfeld F (1995) J Appl Electrochem 25:187

18. Skerry BS Eden DA (1987) Prog Org Coat 15:269

19. Darowicki K Szocinski M (2004) J Solid State Electrochem 8:346

20. Lee SJ Pyun SI (2007) J Solid State Electrochem 11:829

21. Price C, Hallam D, Heath G, Creagh D, Ashton J (1997) An electrochemical study of waxes for bronze sculpture. In: MacLeod ID, Pennec SL, Robbiola L (eds) Metal 95. Proceedings of the International Conference on Metal Conservation, Semur-en-Auxois (France). James \& James, London, pp 233-241

22. Letardi P, Beccaria A, Marabelli M, D'Ercoli G (2001) Application of electrochemical impedance mesurements as a tool for the characterization of the conservation and protection state of bronze works of art. In: Ashton J, Hallam D (eds) Metal 98. Proceedings of the International Conference on Metal Conservation, Draguignan-Figanières (France). James \& James, London, pp 303-308

23. McNamara CJ Breuker M Helms M Perry TD Mitchell R (2004) J Cult Herit 5:361

24. PROMET project (2008) http://promet.org.gr. Accessed 15 April 2009. 
25. Hallam D, Thurrowgood D, Otieno-Alego V, Creagh D, A. V, et al. (2004) Studies of commercial protective petrochemical coatings on ferrous surfaces of historical and museum objects. In: MacLeod I, Theile JM, Degrigny C (eds) Metal 2001: proceedings of the international conference on metals conservation, Santiago (Chile). Western Australian Museum, Welshpool, pp 297-303

26. Brooman EW (2002) Metal Finish 100:42

27. Yang H, van Ooij WJ (2004) Prog Org Coat 50:149

28. Paliwoda-Porebska G, Rohwerder M, Stratmann M, Rammelt U, Duc LM, Plieth W (2006) J Solid State Electrochem 10:730

29. Beaunier L, Epelboin I, Lestrade JC, Takenouti H (1976) Surf Technol 4:237

30. Feliu S, Galván JC, Feliu Jr S, Simancas J, Bastidas JM, Morcillo M, Almeida EM (1995) J Electroanal Chem 381:1

31. Loveday D, Peterson P, Rodgers B (2004) J Coating Technol 1:46

32. Loveday D, Peterson P, Rodgers B (2004) J Coating Technol 1:88

33. Bastidas JM, Polo JL, Torres CL, Cano E (2001) Corros Sci 43:269

34. Skale S, Dolecek V, Slemnik M (2007) Corros Sci 49:1045

35. Liu WM (1998) Mater Corros 49:576

36. Reiuhard G, Simon P, Rammelt U (1992) Progr Org Coat 20:383

37. Guillaumin V, Landolt D (2002) Corros Sci 44:179

38. Galliano F, Landolt D (2002) Prog Org Coat 44:217 


\section{FIGURE CAPTIONS}

Fig. 1. Aspect of the steel specimens of Set 2, after pre-corrosion, partial cleaning and coating.

Fig. 2. Scheme of the electrochemical cell used for the experiments.

Fig. 3. Corrosion potential $\left(E_{\text {corr }}\right)$ measurements of the different specimens (Set 1$)$ after $1 \mathrm{~h}$ of immersion in the electrolyte.

Fig. 4. Polarisation resistance $\left(R_{\mathrm{p}}\right)$ measurements of the different specimens (Set 1).

Fig. 5. Bode plots obtained from specimen without coating and with specimens 1, 2, 2a and 2b (Set 1).

Fig. 6. Bode plots obtained from specimen without coating and with specimens $3,3 a, 3 b$ and $3 c$ (Set 1$)$.

Fig. 7. Equivalent electrical circuit used to fit EIS data.

Fig. 8. SEM images of coating 1 (a), coating 2 (b) and coating 3 (c) (see Table 1), applied on the steel samples.

Fig. 9. Polarisation resistance $\left(R_{\mathrm{p}}\right)$ measurements of the different specimens (Set 2).

Fig. 10. Bode plots obtained from pre-corroded specimens coated by immersion (Set 2) without artificial ageing.

Fig. 11. Polarisation resistance $\left(R_{\mathrm{p}}\right)$ measurements of Renaissance ${ }^{\mathrm{TM}}$ wax (coating 1), Poligen ${ }^{\mathrm{TM}}$ ES-91009 (coating 2) and Paraloid ${ }^{\mathrm{TM}}$ B-72 (coating 3) applied in different conditions (Sets 1, 2 and 3).

Fig. 12. Bode plots obtained from clean specimens coated by immersion (Set 3). 
Table 1. Characteristics of colourless organic coatings and corrosion inhibitors applied on the steel surface.

\begin{tabular}{|c|c|c|c|c|c|c|c|c|c|}
\hline \multirow{2}{*}{ Organic Coating } & \multicolumn{3}{|c|}{$\begin{array}{l}\text { Clean Surface - brushing } \\
\text { (Set 1) }\end{array}$} & \multicolumn{3}{|c|}{$\begin{array}{l}\text { Pre-corroded surface - immersion } \\
\text { (Set 2) }\end{array}$} & \multicolumn{3}{|c|}{$\begin{array}{l}\text { Clean surface }- \text { immersion } \\
(\text { Set } 3)\end{array}$} \\
\hline & Specimen & $\begin{array}{l}\text { Thickness } \\
\mu \mathrm{m}\end{array}$ & $\begin{array}{c}\text { Standard } \\
\text { Deviation }\end{array}$ & Specimen & $\begin{array}{c}\text { Thickness } \\
\mu \mathrm{m}\end{array}$ & $\begin{array}{l}\text { Standard } \\
\text { Deviation }\end{array}$ & Specimen & $\begin{array}{l}\text { Thickness } \\
\mu \mathrm{m}\end{array}$ & $\begin{array}{c}\text { Standard } \\
\text { Deviation }\end{array}$ \\
\hline Without Organic Coating & 0 & - & - & $\mathrm{C} 0$ & - & - & - & - & - \\
\hline Renaissance $^{\mathrm{TM} \mathrm{a}}$ & 1 & 1 & 0 & $\begin{array}{l}\text { C1-N } \\
\text { C1-A }\end{array}$ & $\begin{array}{c}4 \\
16\end{array}$ & $\begin{array}{l}2 \\
7\end{array}$ & $\mathrm{X} 1$ & 3 & 1 \\
\hline Poligen $^{\mathrm{TM}}$ ES-91009 ${ }^{\mathrm{b}}$ & 2 & 1 & 1 & $\begin{array}{l}\mathrm{C} 2-\mathrm{N} \\
\mathrm{C} 2-\mathrm{A}\end{array}$ & $\begin{array}{l}27 \\
42\end{array}$ & $\begin{array}{l}15 \\
26\end{array}$ & $\mathrm{X} 2$ & 23 & 15 \\
\hline Poligen $^{\mathrm{TM}}$ ES-91009 + M435 & $2 \mathrm{a}$ & 3 & 3 & $\begin{array}{l}\mathrm{C} 2 \mathrm{a}-\mathrm{N} \\
\mathrm{C} 2 \mathrm{a}-\mathrm{A}\end{array}$ & $\begin{array}{l}62 \\
79\end{array}$ & $\begin{array}{l}39 \\
38\end{array}$ & - & - & - \\
\hline Poligen ${ }^{\mathrm{TM}}$ ES-91009 + M370 & $2 b$ & 4 & 4 & $\begin{array}{l}\mathrm{C} 2 \mathrm{~b}-\mathrm{N} \\
\mathrm{C} 2 \mathrm{~b}-\mathrm{A}\end{array}$ & $\begin{array}{l}33 \\
33\end{array}$ & $\begin{array}{l}19 \\
22\end{array}$ & - & - & - \\
\hline Paraloid $^{\mathrm{TM}} \mathrm{B}-72^{\mathrm{e}}$ & 3 & 7 & 4 & $\begin{array}{l}\mathrm{C} 3-\mathrm{N} \\
\mathrm{C} 3-\mathrm{A}\end{array}$ & $\begin{array}{l}6 \\
7\end{array}$ & $\begin{array}{l}4 \\
2\end{array}$ & $\mathrm{X} 3$ & 7 & 1 \\
\hline Paraloid $^{\mathrm{TM}} \mathrm{B}-72+\mathrm{M} 435$ & $3 a$ & 6 & 4 & - & - & - & - & - & - \\
\hline Paraloid ${ }^{\mathrm{TM}} \mathrm{B}-72+\mathrm{M} 109^{\mathrm{f}}$ & $3 b$ & 6 & 4 & $\begin{array}{l}\text { C } 3 b-N \\
\text { C3b-A }\end{array}$ & $\begin{array}{c}12 \\
7\end{array}$ & $\begin{array}{l}5 \\
2\end{array}$ & - & - & - \\
\hline Paraloid ${ }^{\mathrm{TM}} \mathrm{B}-72+$ Alkaterge- $\mathrm{T}^{\mathrm{g}}$ & $3 \mathrm{c}$ & 10 & 5 & $\begin{array}{l}\mathrm{C} 3 \mathrm{c}-\mathrm{N} \\
\mathrm{C} 3 \mathrm{c}-\mathrm{A}\end{array}$ & $\begin{array}{l}6 \\
8\end{array}$ & $\begin{array}{l}3 \\
4\end{array}$ & - & - & - \\
\hline
\end{tabular}

${ }^{\mathrm{a}}$ Renaissance ${ }^{\mathrm{TM}}$ is a microcrystalline wax from the Picreator Enterprises Company.

${ }^{\mathrm{b}}$ Poligen ${ }^{\mathrm{TM}}$ ES-91009 is an ethylene wax in water (liquid) from the BASF Company.

${ }^{\mathrm{c}} \mathrm{M} 435$ is a corrosion inhibitor a blend of triazoles from the Cortec Corporation.

${ }^{\mathrm{d}} \mathrm{M} 370$ is a corrosion inhibitor an ammonium salt of tricarboxylic acid from the Cortec Corporation.

${ }^{\mathrm{e}}$ Paraloid ${ }^{\mathrm{TM}} \mathrm{B}-72$ is a $15 \%$ (by volume) acrylic resin in acetone (liquid) from the Rohm and Haas Company.

${ }^{\mathrm{f}} \mathrm{M} 109$ is a corrosion inhibitor a calcium sulphonate from the Cortec Corporation.

${ }^{g}$ Alkaterge-T is a corrosion inhibitor a bis-oxazoline from the Dow Chemical Company.

C: Pre-corroded specimen, coated by immersion

$\mathrm{N}$ : Non artificially aged coating.

A: Artificially aged coating.

$\mathrm{X}$ : Clean specimen, coated by immersion. 
Table 2. Parameters used for the fitting of EIS data (Set 1) using the equivalent electrical circuit of Fig. 7.

\begin{tabular}{|c|c|c|c|c|c|c|}
\hline \multirow[b]{2}{*}{ Specimen } & \multicolumn{2}{|c|}{$\mathrm{CPE}_{1}$} & \multirow[t]{2}{*}{$R_{1} / \Omega \mathrm{cm}^{2}$} & \multicolumn{2}{|l|}{$\mathrm{CPE}_{2}$} & \multirow[t]{2}{*}{$R_{2} / \Omega \mathrm{cm}^{2}$} \\
\hline & $\frac{Y_{1}}{/ \mathrm{F} \mathrm{cm}^{-2} \mathrm{~s}^{-(1-\alpha 1)}}$ & $\alpha_{1}$ & & $\frac{Y_{2}}{/ \mathrm{F} \mathrm{cm}^{-2} \mathrm{~s}^{-(1-\alpha .2)}}$ & $\alpha_{2}$ & \\
\hline 0 & - & - & - & $2.8 \times 10^{-3}$ & 0.74 & $2.7 \times 10^{3}$ \\
\hline 1 & $0.4 \times 10^{-3}$ & 0.80 & 23 & $0.3 \times 10^{-3}$ & 0.79 & $3.0 \times 10^{3}$ \\
\hline 2 & $0.4 \times 10^{-3}$ & 0.76 & $2.1 \times 10^{3}$ & $59 \times 10^{-3}$ & 0.51 & - \\
\hline $2 \mathrm{a}$ & $1.2 \times 10^{-6}$ & 0.76 & $82 \times 10^{3}$ & $2.7 \times 10^{-5}$ & 0.58 & - \\
\hline $2 b$ & $8.9 \times 10^{-9}$ & 0.96 & $281 \times 10^{3}$ & $8.3 \times 10^{-7}$ & 0.47 & - \\
\hline 3 & $3.0 \times 10^{-7}$ & 0.56 & $17 \times 10^{3}$ & $4.6 \times 10^{-6}$ & 0.50 & $35 \times 10^{3}$ \\
\hline $3 a$ & $0.4 \times 10^{-3}$ & 0.50 & 407 & $1.2 \times 10^{-3}$ & 0.82 & $1.4 \times 10^{3}$ \\
\hline $3 b$ & $4.5 \times 10^{-7}$ & 0.65 & $32 \times 10^{3}$ & $1.0 \times 10^{-6}$ & 0.63 & $1.3 \times 10^{6}$ \\
\hline $3 \mathrm{c}$ & $2.1 \times 10^{-7}$ & 0.65 & $8 \times 10^{3}$ & $7.6 \times 10^{-6}$ & 0.54 & $29 \times 10^{3}$ \\
\hline
\end{tabular}


Table 3. Parameters used for the fitting of EIS data (Set 2) using the equivalent electrical circuit of Fig. 7.

\begin{tabular}{|c|c|c|c|c|c|c|}
\hline \multirow[b]{2}{*}{ Specimen } & \multicolumn{2}{|c|}{$\mathrm{CPE}_{1}$} & \multirow[t]{2}{*}{$R_{1} / \Omega \mathrm{cm}^{2}$} & \multicolumn{2}{|l|}{$\mathrm{CPE}_{2}$} & \multirow[t]{2}{*}{$R_{2} / \Omega \mathrm{cm}^{2}$} \\
\hline & $\begin{array}{c}Y_{1} \\
/ \mathrm{F} \mathrm{cm}^{-2} \mathrm{~s}^{-(1-\alpha 1)}\end{array}$ & $\alpha_{1}$ & & $\begin{array}{c}Y_{2} \\
/ \mathrm{F} \mathrm{cm}^{-2} \mathrm{~s}^{-(1-\alpha 2)}\end{array}$ & $\alpha_{2}$ & \\
\hline $\mathrm{C} 0$ & $1.2 \times 10^{-3}$ & 0.67 & 31 & $2.2 \times 10^{-3}$ & 0.71 & $6.0 \times 10^{3}$ \\
\hline $\mathrm{C} 2-\mathrm{N}$ & $2.5 \times 10^{-10}$ & 0.96 & $140 \times 10^{3}$ & $7.8 \times 10^{-8}$ & 0.37 & $3.3 \times 10^{6}$ \\
\hline $\mathrm{C} 2 \mathrm{a}-\mathrm{N}$ & $3.5 \times 10^{-7}$ & 0.88 & $2.7 \times 10^{3}$ & $2.3 \times 10^{-5}$ & 0.64 & $930 \times 10^{3}$ \\
\hline $\mathrm{C} 2 \mathrm{~b}-\mathrm{N}$ & $4.7 \times 10^{-10}$ & 0.92 & $1.1 \times 10^{6}$ & $5.2 \times 10^{-8}$ & 0.42 & $65 \times 10^{6}$ \\
\hline $\mathrm{C} 3-\mathrm{N}$ & $7.3 \times 10^{-8}$ & 0.64 & $2.0 \times 10^{3}$ & $1.5 \times 10^{-6}$ & 0.54 & $31 \times 10^{3}$ \\
\hline $\mathrm{C} 3 \mathrm{~b}-\mathrm{N}$ & $1.5 \times 10^{-8}$ & 0.68 & $100 \times 10^{3}$ & $7.5 \times 10^{-7}$ & 0.25 & $2.1 \times 10^{6}$ \\
\hline $\mathrm{C} 3 \mathrm{c}-\mathrm{N}$ & $8.8 \times 10^{-10}$ & 0.94 & $65 \times 10^{3}$ & $5.5 \times 10^{-7}$ & 0.23 & $1.4 \times 10^{6}$ \\
\hline
\end{tabular}


Table 4. Parameters used for the fitting of EIS data (Set 3) using the equivalent electrical circuit of Fig. 7.

\begin{tabular}{ccccccc}
\hline \multirow{2}{*}{ Specimen } & \multicolumn{1}{c}{$\mathrm{CPE}_{1}$} & & $R_{1} / \Omega \mathrm{cm}^{2}$ & $\mathrm{CPE}_{2}$ & $R_{2} / \Omega \mathrm{cm}^{2}$ \\
& $/ \mathrm{F} \mathrm{cm}^{-2} \mathrm{~s}^{-(1-\alpha 1)}$ & $\alpha_{1}$ & & $/ \mathrm{F} \mathrm{cm}^{-2} \mathrm{~s}^{-(1-\alpha 2)}$ & $\alpha_{2}$ & \\
\hline $\mathrm{X} 1$ & $4.7 \times 10^{-9}$ & 0.85 & $17 \times 10^{3}$ & $8.2 \times 10^{-6}$ & 0.45 & $85 \times 10^{3}$ \\
$\mathrm{X} 2$ & $2.3 \times 10^{-9}$ & 0.83 & $200 \times 10^{3}$ & $3.0 \times 10^{-7}$ & 0.66 & $3 \times 10^{6}$ \\
$\mathrm{X} 3$ & $1.2 \times 10^{-9}$ & 0.92 & $67 \times 10^{3}$ & $3.3 \times 10^{-7}$ & 0.50 & $250 \times 10^{3}$ \\
\hline
\end{tabular}

